\title{
CURRENT TRENDS IN PROSTATE CANCER ETIOLOGY, PATHOGENESIS AND DIAGNOSTICS
}

\author{
Kristofs Folkmanis ${ }^{1,2, \#}$, Elizabete Junk ${ }^{1,2}$, Evelīna Merdane ${ }^{1}$, Inese Folkmane ${ }^{1}$, \\ Valdis Folkmanis ${ }^{1}$, and Sergejs Isajevs ${ }^{1,3}$ \\ ${ }^{1}$ Faculty of Medicine, University of Latvia, 3 Jelgavas Str., LV-1004, Rīga, LATVIA \\ 2 St. Bonifatius Hospital, 13 Wilhelm Str., 49808, Lingen (Ems), GERMANY \\ ${ }^{3}$ Rìga East University Hospital, 2 Hipokrāta Str., LV-1038, Rīga, LATVIA \\ \# Corresponding author, kristofs87@inbox.lv
}

Communicated by Ingrīda Rumba-Rozenfelde

\begin{abstract}
Prostate cancer $(\mathrm{PCa})$ remains the second most commonly diagnosed cancer in men, with an estimated 1.1 million diagnoses worldwide in 2012, accounting for $15 \%$ of all cancers diagnosed. In many cases, successful treatment of prostate cancer is difficult due to late detection and rate of metastasis. Importantly, the tumours of many patients with prostate cancer become refractory to androgen therapy and progress to metastatic castration-resistant disease. An effective treatment course of prostate cancer patients requires predictive biomarkers in metastatic castrationresistant prostate cancer that support individual treatment. Different risk classification tools have been developed to distinguish patients with early PCa according to the prognosis, including the D'Amico classification system, the Cancer of the Prostate Risk Assessment score, and the National Comprehensive Cancer Network risk groups classification. Unfortunately, there is still no single, universal, cheap, non-invasive, early prostate cancer diagnostic tool, as serum prostate specific antigen (PSA) has not approved expectations and is not implemented in standardised prostate cancer screening. The aim of this review was to provide current state of art knowledge of prostate cancer screening, diagnosis, staging and future perspectives and directions.
\end{abstract}

Keywords: personalised medicine, prostate cancer screening, prostate specific antigen, exosomal biomarkers.

\section{EPIDEMIOLOGY}

Prostate cancer remains the second most commonly diagnosed cancer in men, with an estimated 1.1 million diagnoses worldwide in 2012, accounting for $15 \%$ of all cancers diagnosed (D'Amico et al., 2000; Kim and Kim, 2011; Jahn et al., 2015; Brajtbord et al., 2017; Kretschmer and Tilki, 2017; Filella et al., 2018; Ingrosso et al., 2018; Siegel et al., 2019; Mottet et al., 2020).

The frequency of autopsy-detected PCa is roughly the same worldwide. Series of autopsy studies showed a prevalence of PCa at age $<30$ years of 5\% (95\% CI: 3-8\%), increasing by an odds ratio of $1.7(1.6-1.8)$ per decade, to a prevalence of $59 \%(48-71 \%)$ by age $>79$ years.

The incidence of $\mathrm{PCa}$, however, varies widely between different countries, being the highest in Australia/New Zealand and Northern America (age-standardized rates [ASR] of
111.6 and 97.2 per 100000 , respectively), and in Western and Northern Europe (ASR 94.9 and 85), largely due to the use of prostate specific antigen (PSA) testing and the aging population (Mottet et al., 2020).

In Latvia in 2017, PCa was the most commonly diagnosed cancer in men. In 2017, prostate cancer for the first time was detected in 1286 males, and 427 died in Latvia (LSM.LV, 2019).

At the end of 2017, 8665 men were registered with a diagnosis of prostate cancer. $48 \%$ of those registered lived for more than five years since the diagnosis. Among first-time diagnoses, the average incidence of prostate cancer in men since 2010 was $20.15 \%$.

Epidemiological studies showed that $16 \%$ died of prostate cancer in 2016 in the first year after diagnosis. The fiveyear survival for prostate cancer in 2017 was $65.2 \%$. The 
most common (43\%) tumour was detected in stage II. In stage I, the tumour was detected in $25 \%$ of cases. According to statistics, the risk of developing prostate cancer increases from the age of 40 . The highest risk of malignant prostate tumours is in men aged 60-80\% (Aumüller, 1979).

\section{AETIOLOGY}

Prostate cancer risks factors. Family history/genetics. Family history and racial/ethnic background are associated with increased PCa incidence suggesting a genetic predisposition. However, only a small subpopulation of men with PCa ( 9\%) have true hereditary disease. This is defined as three or more affected relatives, or at least two relatives who have developed early-onset $\mathrm{PCa}(<55$ years) (Mottet $e t$ al., 2020).

Patients with hereditary PCa usually have a disease onset six-seven years earlier than average, but their clinical course does not seem to differ in other ways, e.g., for disease aggressiveness. Men with African ethnicity origin show a higher incidence of $\mathrm{PCa}$ and generally have a more lethal course of disease.

Of the underlying determinants of genomic diversity and mechanisms between genetic and environmental factors, much remains unknown. Genome-wide association studies have identified 100 common susceptibility loci contributing to the risk for $\mathrm{PCa}$, explaining $\sim 38.9 \%$ of the familial risk for this disease. Furthermore, an incidence of $11.8 \%$ of germline mutations in genes mediating DNA-repair processes was found among men with metastatic PCa. Germline mutations in genes such as $H O X B 13$ and BRCAl/2 have been associated with an increased risk of $\mathrm{PCa}$, and targeted genomic analysis of these genes could offer options to identify families at high risk. Trials of screening for PCa-targeting BRCA mutation carriers are ongoing (Siegel et al., 2019).

Acquired risk factors. As Japanese men move from Japan to California, their risk of PCa increases, approaching that of American men. A wide variety of exogenous/environmental factors have been discussed as being aetiologically important for the risk of progression from latent to clinical PCa. However, currently there are no effective preventative dietary or pharmacological interventions (Mottet et al., 2020).

The single components hypertension and waist circumference $>102 \mathrm{~cm}$ of MetS have been associated with a significantly greater risk of $\mathrm{PCa}$, but conversely, having $>3$ components of MetS is associated with a reduced risk (Siegel et al., 2019).

On a population level, metformin users (but not other oral hypoglycaemics) were found to have decreased risk of PCa diagnosis, compared with never-users. In 540 diabetic participants of the Reduction by Dutasteride of Prostate Cancer Events (REDUCE) study, metformin use was not significantly associated with PCa (Mottet et al., 2020).
A meta-analysis of fourteen large prospective studies did not show an association between blood total cholesterol (TC), high-density lipoprotein cholesterol (HDL), lowdensity lipoprotein cholesterol (LDL) levels and the risk of either overall PCa or high-grade PCa. Results of the REDUCE study also did not show a preventive effect of statins on PCa risk (Mottet et al., 2020).

Within the REDUCE study, obesity was associated with lower risk of low-grade PCa in multivariable analyses, but increased risk of high-grade. This effect seems mainly explained by environmental determinants of height/BMI rather than genetically elevated height or BMI (Mottet et al., 2020).

The association between a wide variety of dietary factors and PCa have been studied (Table 1).

\section{MOLECULAR PATHOLOGY OF PROSTATE CANCER}

The most common histopathological form of prostate cancer is classified as an adenocarcinoma, or glandular cancer, that begins when normal semen-secreting prostate gland cells mutate into cancer cells. The region of prostate gland where the adenocarcinoma is most common is the peripheral zone (Schmelz et al., 2006).

The specialised function of the normal prostate glandular epithelium is to produce and secrete enormously high levels of citrate involves and requires unique intermediary metabolism activities that are not generally associated with other normal mammalian cells. The accumulation of zinc by these cells is an essential factor in this unique metabolic relationship. In malignancy, the normal zinc-accumulating citrate-producing epithelial cells are metabolically transformed to citrate-oxidising cells that lose the ability to accumulate zinc.

The protein ZIP1 is responsible for the active transport of zinc into prostate cells. One of the zinc's important roles is to change the metabolism of the cell in order to produce citrate, an important component of semen.

Table 1. Dietary factors that have been associated with prostate cancer (adapted from Siegel et al., 2019)

\begin{tabular}{|l|l|}
\hline Alcohol & $\begin{array}{l}\text { High alcohol intake, but also total abstention from } \\
\text { alcohol have been associated with a higher risk of PCa } \\
\text { and PCa-specific mortality }\end{array}$ \\
\hline Dairy & $\begin{array}{l}\text { A weak correlation between insulin-like growth fac- } \\
\text { tor-I (IGF-1) levels and high intake of protein from } \\
\text { dairy products and the risk of PCa was found }\end{array}$ \\
\hline Fat & $\begin{array}{l}\text { No association between intake of long-chain omega-3 } \\
\text { poly-unsaturated fatty acids and PCa was found. A } \\
\text { relation between intake of fried foods and risk of PCa } \\
\text { may exist }\end{array}$ \\
\hline $\begin{array}{l}\text { Vitamin D } \\
(25(O H) D)\end{array}$ & $\begin{array}{l}\text { An U-shaped association has been observed, with both } \\
\text { low- and high vitamin-D concentrations being a } \\
\text { ssociated with an increased risk of PCa, and more } \\
\text { strongly for high-grade disease }\end{array}$ \\
\hline $\begin{array}{l}\text { Selenium/ } \\
\text { Vitamin }\end{array}$ & $\begin{array}{l}\text { Selenium and Vitamin E were found not to affect PCa } \\
\text { incidence }\end{array}$ \\
\hline
\end{tabular}


Prostate cancer cells are generally devoid of zinc. This allows prostate cancer cells to save energy by not making citrate, and utilise the new abundance of energy to grow and spread. Zinc inhibits NF- $\mathrm{NB}$ pathways, is anti-proliferative and induces apoptosis in abnormal cells. Unfortunately, oral ingestion of zinc is ineffective since high concentrations of zinc into prostate cells is not possible without the active transporter, ZIP1 (Rosenberg et al., 2005).

Loss of cancer suppressor genes early in the prostatic carcinogenesis have been localised to chromosomes 8p, 10q, $13 \mathrm{q}$, and $16 \mathrm{q}$.

p53 mutations in the primary prostate cancer are relatively low and are more frequently seen in metastatic settings; hence, p53 mutations are a late event in the pathology of prostate cancer. Other tumour suppressor genes that are thought to play a role in prostate cancer include PTEN (gene) and KAIl. "Up to 70 percent of men with prostate cancer have lost one copy of the PTEN gene at the time of diagnosis" (Leav et al., 2010). The relative frequency of loss of E-cadherin and CD44 has also been observed.

RUNX2 is a transcription factor that prevents cancer cells from undergoing apoptosis, thereby contributing to the development of prostate cancer (Zha nd Huang, 2009).

The PI3k/Akt signaling cascade works with the transforming growth factor beta/SMAD signaling cascade to ensure prostate cancer cell survival and protection against apoptosis (Watanabe et al., 2009). X-linked inhibitor of apoptosis (XIAP) is hypothesised to promote prostate cancer cell survival and growth and is a target of research, because if this inhibitor can be shut down then the apoptosis cascade can carry on its function in preventing cancer cell proliferation (Senapati et al., 2010). Macrophage inhibitory cytokine-1 (MIC-1) stimulates the focal adhesion kinase (FAK) signaling pathway that leads to prostate cancer cell growth and survival (Narizhneva et al., 2009).

The androgen receptor helps prostate cancer cells to survive and is a target for many anti-cancer research studies; so far, inhibiting the androgen receptor has only proven to be effective in mouse studies (Yao et al., 2010).

Prostate specific membrane antigen (PSMA) stimulates the development of prostate cancer by increasing folate levels for cancer cells to use to survive and grow; PSMA increases available folates for use by hydrolysing glutamated folates (Goldstein et al., 2010).

A series of studies involved introduced viruses known to cause cancerous mutation in prostate cells: AKT, ERG, and AR into isolated samples of basal and luminal cells and grafting of the treated tissue into mice. After 16 weeks, none of the luminal samples had undergone malignant mutation, while the basal samples had mutated into prostatelike tubules that then developed malignancy and formed cancerous tumours, which appeared identical to human samples under magnification. This led to the conclusion that the prostate basal cell may be the most likely the "site of origin" of prostate cancer (Ghosh and Myers, 1998).

Arachidonate 5-lipoxygenase has been identified as playing a significant role in the survival of prostate cancer cells (Rosenberg et al., 2005; Zha and Huang 2009; Leav et al., 2010). Medications which target this enzyme may be an effective therapy for limiting tumour growth and cancer metastasis as well as inducing programmed cell death in cancer cells (Rosenberg et al., 2005; Zha and Huang, 2009; Leav et al., 2010). In particular, arachidonate 5-lipoxygenase inhibitors produce massive, rapid programmed cell death in prostate cancer cells (Greene et al., 2011; Bishayee and KhudaBukhsh, 2013; Reedy et al., 2020).

Almost all prostate cancers are acinar adenocarcinomas. These cancers develop from the gland cells of prostate. Other types of prostate cancer include: sarcomas, small cell carcinomas, neuroendocrine tumors, transitional cell carcinomas. These types of prostate cancer are rare. Up to $95 \%$ of prostate cancer cases are almost certain to be adenocarcinomas.

Some prostate cancers can grow and spread quickly, but most grow slowly. In fact, autopsy studies show that many older men (and even some younger men) who died of other causes also had prostate cancer that never affected them during their lives. In many cases neither they nor their doctors even knew they had it (van der Pol et al., 2012).

Some research suggests that prostate cancer starts out as a pre-cancerous condition, although this is not yet known for sure. These conditions are sometimes found when a man has a prostate biopsy (van der Pol et al., 2012).

In PIN, there are changes in how the prostate gland cells look microscopically, but the abnormal cells do not look like they are growing into other parts of the prostate (like cancer cells would). Based on how abnormal the patterns of cells look, they are classified as:

Low-grade PIN: the patterns of prostate cells appear almost normal; High-grade PIN: the patterns of cells look more abnormal. PIN begins to appear in the prostates of some men as early as in their 20s (van der Pol et al., 2012).

Many males begin to develop low-grade PIN when they are younger but do not necessarily develop prostate cancer. The possible link between low-grade PIN and prostate cancer is still unclear.

If high-grade PIN is found, there is about a $20 \%$ chance that there is cancer in another area of prostate (van der Pol et al., 2012).

\section{PROSTATE CANCER SCREENING}

PSA population screening is still a debatable topic. There are publications and large-scale studies that justify extensive PSA screening, such as the Swedish study, which explains the specific five-year increase in prostate tumour sur- 
vival by targeted PSA screening from 1960 to 1988 (Helgesen et al. 1996; Lu-Yao et al., 2002). But at the same time, there are publications in the scientific literature that challenge the purpose fulness of routine PSA screening, such as a comparison of Seattle and Connecticut patient data - the first city had extensive routine PSA screening, and the second population rarely tested, but no statistically significant differences in prostate tumour-specific mortality between the cities (Lu-Yao et al., 2002). Despite that PSA value hasn't the power to be included in a general screening programme, there is no better PCa mesurment, risk stratification, diagnostic and therapeutic course affecting tool as PSA measurement. No PSA adapted measurement nor alternative values has proved to be superior as PSA value alone (Mottet et al., 2020).

\section{CLINICAL DIAGNOSTICS}

Prostate cancer is usually suspected on the basis of DRE and/or PSA levels. Definitive diagnosis depends on histopathological verification of adenocarcinoma in prostate biopsy cores or specimens from transurethral resection of the prostate (TURP) or prostatectomy for benign prostatic enlargement (BPE) (Mottet et al., 2020).

Most PCas are located in the peripheral zone and may be detected by DRE when the volume is $>0.2 \mathrm{ml}$. In $\sim 18 \%$ of cases, PCa is detected by suspect DRE alone, irrespective of the PSA level. Suspect DRE in patients with a PSA level $<2 \mathrm{ng} / \mathrm{ml}$ has a positive predictive value of $5-30 \%$. Abnormal DRE is associated with an increased risk of a higher Gleason score and is an indication for biopsy (Mottet et al., 2020).

The use of PSA as a serum marker has revolutionised PCa diagnosis. Prostate-specific antigen is organ- but not cancer-specific; therefore, it may be elevated in benign prostatic hypertrophy $(\mathrm{BPH})$, prostatitis and other nonmalignant conditions. As an independent variable, PSA is a better predictor of cancer than either DRE or transrectal ultrasound (TRUS). The PSA has value for the risk stratification of prostate cancer.

There are no agreed standards defined for measuring PSA. PSA is a continuous parameter, with higher levels indicating greater likelihood of PCa. Many men may harbour PCa despite having low serum PSA. The use of nomograms may help in predicting indolent PCa (Mottet et al., 2020).

Prostate specific antigen density is the level of serum PSA divided by the TRUS-determined prostate volume. The higher the PSA density, the more likely it is that the PCa is clinically significant (Mottet et al., 2020).

There are two methods of measuring PSA kinetics:

- PSA velocity (PSAV): absolute annual increase in serum PSA (ng/ml/year);
- PSA doubling time (PSA-DT): which measures the exponential increase in serum PSA over time.

Prostate specific antigen velocity and PSA-DT may have a prognostic role in treating $\mathrm{PCa}$, but limited diagnostic use because of background noise (total prostate volume, and $\mathrm{BPH}$ ), different intervals between PSA determinations, and acceleration/deceleration of PSAV and PSA-DT over time. These measurements do not provide additional information compared with PSA alone (Mottet et al., 2020).

Free/total (f/t) PSA ratio can be used to differentiate BPH from PCa. It stratifies the risk of PCa in men with 4-10 $\mathrm{ng} / \mathrm{ml}$ total PSA and negative DRE. Prostate cancer was detected by biopsy in $56 \%$ of men with $\mathrm{f} / \mathrm{t} \mathrm{PSA}<0.10$, but in only $8 \%$ with $\mathrm{f} / \mathrm{t}$ PSA $>0.25 \mathrm{ng} / \mathrm{ml}$. Free/total PSA is of no clinical use if total serum PSA is $>10 \mathrm{ng} / \mathrm{ml}$ or during follow up of known PCa.

Free/total PSA must be used cautiously because it may be adversely affected by several pre-analytical and clinical factors (e.g., instability of free PSA at $4{ }^{\circ} \mathrm{C}$ and room temperature, variable assay characteristics, and concomitant $\mathrm{BPH}$ in large prostates) (Mottet et al., 2020).

A few assays measuring a panel of kallikreins in serum or plasma are now commercially available, including the FDA-approved Prostate Health Index (PHI) test, combining free and total PSA and the (-2)pro-PSA isoform (p2PSA), and the four kallikrein $(4 \mathrm{~K})$ score test (measuring free, intact and total PSA and kallikrein-like peptidase 2 [hK2]). Both tests are intended to reduce the number of unnecessary prostate biopsies in PSA-tested men.

The Prostate Health Index (PHI) is a new formula that combines all three forms (total PSA, free PSA and p2PSA) into a single score that can be used to aid in clinical decision-making (Catalona et al., 2011). PHI is calculated using the following formula: ([-2]proPSA/free PSA) $\times \sqrt{ } \mathrm{PSA}$.

A few prospective multicentre studies demonstrated that both the PHI and 4K test out-performed f/t PSA PCa detection, with an improved prediction of clinically significant $\mathrm{PCa}$ in men with a PSA between $2-10 \mathrm{ng} / \mathrm{ml}$. In a head to head comparison both tests performed equally (Mottet et al., 2020).

\section{TISSUE AND SERUM BIOMARKERS}

Recently, different tissue and serum biomarkers for the diagnsotics of prostate cancer have been proposed. They are based on cancer-specific somatic mutations detection, circulating tumour cell free DNA, and miRNA.

Prostate cancer gene 3 (PCA3) is a prostate-specific, noncoding mRNA biomarker that is detectable in urine sediments obtained after three strokes of prostatic massage during DRE. The commercially available Progensa urine test for PCA3 is superior to total and percent-free PSA for detection of PCa in men with elevated PSA, as it shows signif- 
icant increases in the area under the receiver-operator characteristic curve for positive biopsies.

The PCA3 score increases with PCa volume, but there are conflicting data about whether it independently predicts Gleason score, and its use for monitoring in active surveillance (AS) is, as yet, not confirmed. Currently, the main indication for the Progensa test is to determine whether a repeat biopsy is needed after an initially negative biopsy, but its clinical effectiveness for this purpose is uncertain (Mottet et al., 2020).

Additional information may be gained by the Progensa DRE urine test for PCA3, the serum 4Kscore, PHI tests or a tissue-based epigenetic test (Confirm MDx).

The role of PHI and Progensa $P C A 3$ in deciding whether to take a repeat biopsy in men who had a previous negative biopsy is uncertain and probably not cost-effective. The Confirm MDx test is based on the concept that benign prostatic tissue in the vicinity of a PCa focus shows distinct epigenetic alterations.

If, due to sampling bias, the PCa is missed at biopsy, demonstration of epigenetic changes in the adjacent benign tissue would indicate the presence of carcinoma.

The Confirm $M D X$ test quantifies the methylation level of promoter regions of three genes (RASSF1, GSTP1 and APC) in benign prostatic tissue. A multicentre study found a negative predictive value of $88 \%$ when methylation was absent in all three markers, implying that a repeat biopsy could be avoided in these men. Given the limited available data, no recommendation can be made regarding its routine application (Mottet et al., 2020).

The Prolaris test (Myriad Genetics) measures the expression of 31 cell-cycle associated genes in biopsy-derived PCa tissue and may be of clinical use to determine whether a patient needs curative treatment or may have his treatment deferred.

Similarly, Oncotype Dx is a RNA-based test based on twelve carcinoma-associated genes and five reference genes, which can be applied to carcinoma tissue in prostate biopsies to determine the aggressiveness of the carcinoma. Both tests were shown in prospective studies to provide prognostic information in men with clinically localised $\mathrm{PCa}$, additional to conventional clinicopathological parameters, including the Gleason score and PSA level. The results of prospective multicentre studies are awaited before a recommendation can be made regarding their routine application (Mottet et al., 2020).

The need for prostate biopsy is based on PSA level and/or suspicious DRE. Age, potential comorbidity, and therapeutic consequences should also be considered and discussed beforehand.

Prostate cancer biopsy and histopathological examination are still the gold standart for the diagnosis of prostate can- cer. Risk stratification is a potential tool for reducing unnecessary biopsies.

Limited PSA elevation alone should not prompt immediate biopsy. The prostate specific antigen level should be verified after a few weeks using the same assay under standardised conditions (i.e., no ejaculation, manipulations, and urinary tract infections [UTIs]) in the same laboratory. Empiric use of antibiotics in an asymptomatic patient in order to lower the PSA should not be undertaken.

Ultrasound (US)-guided biopsy is now the standard of care. A transrectal approach is used for most prostate biopsies, although some urologists prefer a perineal approach. Cancer detection rates are comparable with both approaches (Mottet et al., 2020).

\section{HISTOPATHOLOGICAL EXAMINATION OF PROS- TATE BIOPSY}

Diagnosis of $\mathrm{PCa}$ is based on histology by evaluating hematoxylin-eosin stained slides. The diagnostic criteria include features pathognomonic of cancer, major and minor features favouring cancer and features against cancer. Ancillary staining, including immunohistochemistry and additional (deeper) sections should be considered if a suspect lesion is identified. Diagnostic uncertainty is resolved by intradepartmental or external consultation.

A prostate biopsy that does not contain glandular tissue should be reported as diagnostically inadequate. Mandatory elements to be reported for a carcinoma-positive prostate biopsy are:

- type of carcinoma;

- primary and secondary/worst Gleason grade (per biopsy site and global);

- percentage high-grade carcinoma (global);

- extent of carcinoma (in $\mathrm{mm}$ or percentage) (at least per biopsy site);

- if present: EPE, seminal vesicle invasion, LVI, intraductal carcinoma/cribriform pattern, and peri-neural invasion.

The Gleason score and grade groups are assigned by pathologists based on prostate cancer morphology to describe the loss of tissue structure and order and are strongly correlated with disease aggressiveness and patient outcome.

The Gleason grade is determined by pathologists on hematoxylin and eosin (H\&E) stained tissue specimens based on the architectural growth patterns of the tumour.

Gleason scoring categorises tumour tissue into patterns from 1 (low risk) to 5 (high risk). Therefore, Gleason score Grade groups have long been recognised as being strongly associated with the risk of prostate cancer recurrence and metastasis. 
Hovewer, the Gleason score has substantial inter-observer variability, limiting its usefulness for individual patients. In addition, specialised urological pathologists have greater concordance; however, such expertise is not widely available. Therefore, standardisation of the assessment is important.

Digital pathology and artificial Intelligence (AI) could potentially solve the problem of inter-observer agreement. In the global market, the existing software in digital pathology has been developed mainly in the EU, the USA, Great Britain, Japan, China, and Southern Korea and is designed for online consultations and morphometric data analysis. Digital pathology in prostate cancer diagnosis is an up-andcoming area, and many projects are under development and at the testing stage (Ström \& Kartasalo et al., 2020).

The 2005 International Society of Urological Pathology (ISUP) modified Gleason score of biopsy-detected PCa comprises the Gleason grade or the most extensive (primary pattern) pattern, plus the second most common pattern (secondary pattern), if two are present. If one pattern is present, it needs to be doubled to yield the Gleason score. For three grades, the Gleason score comprises the most common grade plus the highest grade, irrespective of its extent. When a carcinoma is largely grade $4 / 5$, identification of $<5 \%$ of Gleason grade 2 or 3 glands should not be incorporated in the Gleason score.

A Gleason score $<6(3+3=6)$ should not be given based on prostate biopsies. In addition to reporting of the carcinoma features for each biopsy, an overall (or global) Gleason score based on the carcinoma-positive biopsies can be provided.

The ISUP 2014 Gleason grading represents a compression of Gleason scores $<6$ to ISUP grade 1 , and Gleason scores 9-10 to ISUP grade 5, whereas a Gleason score of 7 is expanded to ISUP grade 2, i.e. $7(3+4)$ and ISUP grade 3 , i.e. $7(4+3)$.

In September 2019, the novel ISUP 2019 consensus conference guidelines were recommended. Topics brought to consensus included the following approaches to reporting of Gleason pattern 4 and 5, report of invasive cribriform carcinoma and intraductal carcinoma (IDC) and individual versus aggregate grading of biopsies.

Gleason patterns 4 and 5 quantities, minor/tertiary patterns and the percentage of Gleason pattern 4 should be reported for all Gleason score 7 (Grade group II and III) cases; however, for radical prostatectomy the tertiary pattern of Gleasons score 4 and 5 should be included if it consists more than $5 \%$ of the tumour volume; if less it should be reported but not included in overall Gleasons score.

The size of the cribriform carcinoma should be reported in all biopsy samples. In addition, the incorporate intraductal carcinoma (IDC) should be incorporated into grading when invasive carcinoma is present; however, IDC should not been graded if the invasive carcinoma has not been observed.

In systematic biopsies the separate Gleason score (ISUP grade groups) should be reported for each biopsy site, whereas for MRI targeted biopsies a global (aggregate) Gleason score (ISUP grade groups) should be reported for each suspicios MRI lesion (van Leenders et al., 2020).

\section{PROGNOSTIC RELEVANCE OF STRATIFICATION}

A more precise stratification of the clinically heterogeneous subset of intermediate-risk group patients could provide a better framework for their management (Table 2). The adoption of the current ISUP grading system, defining the split-up of Gleason score 7 cancers into ISUP grade 2 (primary Gleason grade 3 ) and ISUP 3 (primary Gleason grade 4), because of their distinct prognostic impact, strengthens such a separation of the intermediate-risk group into a lowintermediate (ISUP grade 2) and high intermediate-risk (ISUP grade 3) group.

Emerging clinical data support this distinction between favourable- and unfavourable-risk patient categories within the intermediate-risk group (Mottet et al., 2020).

Table 3 provides a summary of current state of art guidelines for screening and early detection of prostate cancer.

\section{FOLLOW-UP AFTER TREATMENT WITH CURATIVE INTENT}

After RP, PSA should be undetectable $(<0.1 \mathrm{ng} / \mathrm{ml})$. A PSA of $>0.1 \mathrm{ng} / \mathrm{ml}$ after RP is a signal of residual prostate tissue. After an undetectable PSA is obtained following RP, a PSA $>0.2 \mathrm{ng} / \mathrm{ml}$ and rising, is associated with recurrent disease.

After RT, an increase in PSA $>2 \mathrm{ng} / \mathrm{ml}$ above the nadir, rather than a specific threshold value, is the most reliable sign of recurrence.

Palpable nodules and increasing serum PSA are often signs of local recurrence (Mottet et al., 2020).

Table 2. European Association of Urology risk groups for biochemical recurrence of localised and locally advanced prostate cancer

\begin{tabular}{|l|l|l|l|}
\hline Definition & Intermediate-risk & \multicolumn{1}{l|}{ High-risk } \\
\hline Low-risk & $\begin{array}{l}\text { PSA } 10-20 \mathrm{ng} / \mathrm{ml} \text { or GS } 7 \\
\text { (ISUP grade 2/3) or cT2b } \\
\text { (ISUP grade 1) and cT1-2a }<10 \mathrm{ng} / \mathrm{ml} \text { and GS }<7\end{array}$ & $\begin{array}{l}\text { PSA }>20 \mathrm{ng} / \mathrm{ml} \text { or GS }>7 \\
\text { (ISUP grade 4/5) or cT2c }\end{array}$ & $\begin{array}{l}\text { any PSA any GS cT3-4 or cN+ } \\
\text { Any ISUP grade }\end{array}$ \\
\hline Localised & Locally advanced \\
\hline
\end{tabular}


Table 3. Guidelines for screening and early detection, recommendations

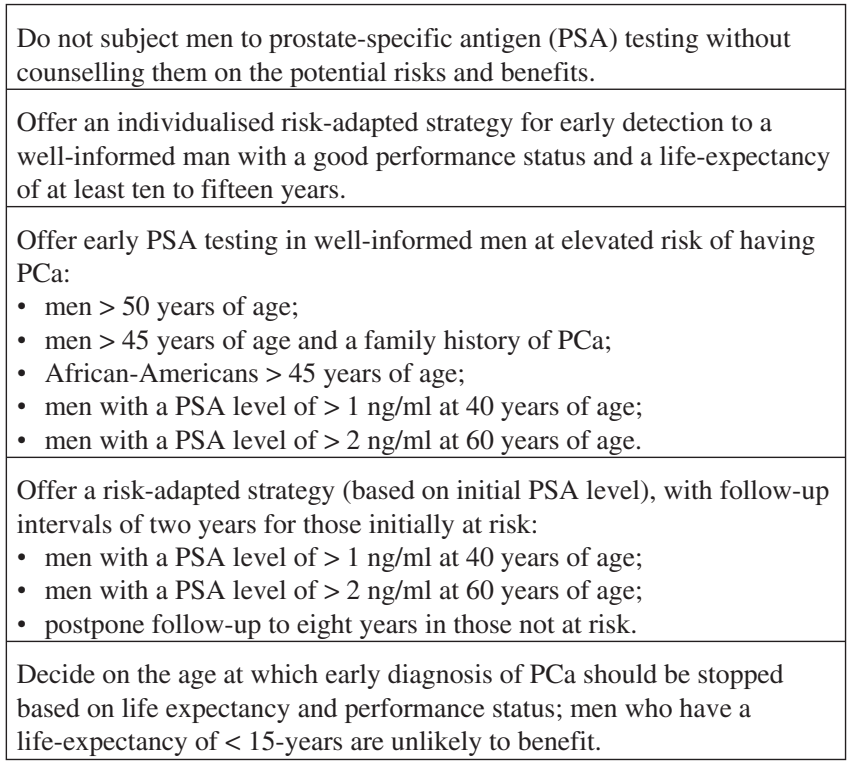

In cases of PSA recurrence after radical prostatectomy with PSA > $1 \mathrm{ng} / \mathrm{ml}$, positron emission tomography (PET)/computed tomography (CT) imaging is recommended using choline or prostate-specific membrane antigen (PMSA) (Mottet et al., 2020).

Eligible patients whose global quality of life is equivalent for up to five years, are advised for active surveillance compared to radical prostatectomy or radiotherapy (Mottet et al., 2020).

It is advised to discuss the negative impact of surgery on urinary and sexual function, as well as the negative impact of radiotherapy on bowel function with patients (Mottet et al., 2020).

\section{CONCLUSIONS AND FUTURE DIRECTIONS}

Prostate cancer is one of the most common malignancies in developed countries and the second cause of cancer death for men (Siegel et al., 2019).

A large proportion of prostate cancer ( $\mathrm{PCa}$ ) cases are latent, which never were destined to progress to metastatic disease. It is of utmost importance to identify which PCa are destined to progress and which would benefit from an early radical treatment.

Prostate-specific antigen (PSA) remains the most used test to detect PCa. Its limited specificity and an elevated rate of overdiagnosis are the main problems associated with PSA testing.

The classic prostate cancer predictive criteria, which stratify the risk of disease progression, are such histopathological criteria like cancer histopathological subtype, Gleason grading system, grade groups, which are assessed during the prostate biopsy by pathologist.
In the past decade, advances in precision oncology have resulted in an increased demand for predictive assays that enable risk stratification for prognosis and risk stratification for disease progression (Helgesen et al., 1996; Tarhan et al., 2005; Thompson, 2006; Soekmadji et al., 2013; Kharaziha et al., 2015; Del Re et al., 2017).

PSA population screening is still a debatable topic. There are publications and large-scale studies that justify extensive PSA screening, such as the Swedish study, which explains the specific five-year increase in prostate tumour survival by targeted PSA screening from 1960 to 1988 (Helgesen et al., 1996; Lu-Yao et al., 2002). But at the same time, there are publications in the scientific literature that challenge the purposefulness of routine PSA screening, such as the comparison of Seattle and Connecticut patient data - the first city had extensive routine PSA screening, the population of the second one was rarely tested, but there was no statistically significant difference in prostate tumour-specific mortality between cities (Lu-Yao et al., 2002). Despite that PSA value does not have the power to be included in a general screening programme, there is no better PCa mesurment, risk stratification, diagnostic and therapeutic course affecting tool than PSA measurement (Mottet et al., 2020). Furthermore, PSA adapted measurement or alternative values have not been proved to be superior as PSA value alone yet (Mottet et al., 2020).

The recently described novel screening diagnostics tools like somatic mutation testing, ctDNA, mRNA and urine exosome seem promising, but validation studies are still required.

The prostate cancer treatment strategy, which is multimodal and based on patient surveillance, serological, histopathological and clinical testing, is currently approved in the recent guidelines.

\section{REFERENCES}

Aumüller, G. (1979). Prostate Gland and Seminal Vesicles. SpringerVerlag, Berlin-Heidelberg. 380 pp.

Azmi, A. S., Bao, B., Sarkar, F. H. (2013). Exosomes in cancer development, metastasis, and drug resistance: A comprehensive review. Cancer Metastasis Rev., 32 (3-4), 623-642.

Bishayee, K., Khuda-Bukhsh, A. R. (2013). 5-lipoxygenase antagonist therapy: A new approach towards targeted cancer chemotherapy. Acta Biochim. Biophys. Sin. (Shanghai), 45 (9), 709-719.

Brajtbord, J. S., Leapman, M. S., Cooperberg, M. R. (2017). The CAPRA score at 10 years: Contemporary perspectives and analysis of supporting studies. Eur. Urol., 71 (5), 705-709.

Catalona, W. J., Partin, A. W., Sanda, M. G., Wei, J. T., Klee, G. G., Bangma, C. H., Slawin, K. M., Marks, L. S., Loeb, S., Broyles, D. L., et al. (2011). A multicenter study of [-2]pro-prostate specific antigen combined with prostate specific antigen and free prostate specific antigen for prostate cancer detection in the 2.0 to $10.0 \mathrm{ng} / \mathrm{ml}$ prostate specific antigen range. J. Urol., 185 (5), 1650-1655.

D'Amico, A. V., Whittington, R., Malkowicz, S. B. (2000). Clinical utility of the percentage of positive prostate biopsies in defining biochemical outcome after radical prostatectomy for patients with clinically localized prostate cancer. J. Clin. Oncol., 18 (6), 1164-1172. 
Del Re, M., Biasco, E., Crucitta, S., Derosa, L., Rofi, E., Orlandini, C., Miccoli, M., Galli, L., Falcone, A., Jenster, G. W. (2017). The detection of androgen receptor splice variant 7 in plasma derived exosomal RNA strongly predicts resistance to hormonal therapy in metastatic prostate cancer patients. Eur. Urol., 71, 680-687.

Filella, X., Fernández-Galan, E., Fernández Bonifacio, R., Foj L. (2018). Emerging biomarkers in the diagnosis of prostate cancer. Pharmgenomics Pers. Med., 11, 83-94.

Ghosh, J., Myers, C. E. (1998). Inhibition of arachidonate 5-lipoxygenase triggers massive apoptosis in human prostate cancer cells. Proc. Natl. Acad. Sci. U.S.A., 95 (22), 13182-13187.

Goldstein, A. S., Huang, J., Guo, C., Garraway, I. P., Witte, O. N. (2010). Identification of a cell of origin for human prostate cancer. Science. 329 (5991), 568-571

Greene, E. R., Huang, S., Serhan, C. N., Panigrahy, D. (2011). Regulation of inflammation in cancer by eicosanoids. Prostaglandins Other Lipid Mediat., 96 (1-4), 27-36.

Helgesen, F., Holmberg, L., Johansson, J. E. (1996). Trends in prostate cancer survival in Sweden, 1960 through 1988, evidence of increasing diagnosis of non-lethal tumours. J. Natl. Cancer Inst., 88 (17), 1216-1221.

Ingrosso, G., Detti, B., Scartoni, D., Lancia, A., Giacomelli, I., Baki, M., Carta, G., Livi, L., Santoni, R. (2018). Current therapeutic options in metastatic castration-resistant prostate cancer. Semin. Oncol., 45, 303-315.

Jahn, J. L, Giovannucci, E. L., Stampfer, M. J. (2015). The high prevalence of undiagnosed prostate cancer at autopsy: Implications for epidemiology and treatment of prostate cancer in the prostate-specific antigen-era. Int. J. Cancer, 137 (12), 2795-2802.

Kharaziha, P., Chioureas, D., Rutishauser, D., Baltatzis, G., Lennartsson, L., Fonseca, P., Azimi, A., Hultenby, K., Zubarev, R., Ullen, A. (2015). Molecular profiling of prostate cancer derived exosomes may reveal a predictive signature for response to docetaxel. Oncotarget, 6, 21740-21754.

Kim, S. J., Kim, S. I. (2011). Current treatment strategies for castration-resistant prostate cancer. Korean J. Urol., 52, 157-165.

Kretschmer, A., Tilki, D. (2017). Biomarkers in prostate cancer: Current clinical utility and future perspectives. Crit. Rev. Oncol. Hematol., 120, 180-193.

Leav, I., Plescia, J., Goel, H. L., Li, J., Jiang, Z., Cohen, R. J., Languino, L. R., Altieri, D. C. (2010). Cytoprotective mitochondrial chaperone TRAP-1 as a novel molecular target in localized and metastatic prostate cancer. Amer. J. Pathol., 176 (1), 393-401.

LSM.LV (2019).

https://www.lsm.lv/raksts/zinas/latvija/visizplatitakais-veza-veids-viriesi em-prostatas-laundabigais-audzejs.a335221/ (accessed 10.08.2021) (in Latvian).

Lu-Yao, G., Albertsen, P. C., Stamford, J. L. (2002). Natural experiment examining impact of aggressive screening and treatment on prostate cancer mortality in two fixed cohorts from Seattle area and Connecticut. BMJ, 325 (7367), 740.

Moore, K., Dalley, A. (1999). Clinically Oriented Anatomy. Lippincott Williams \& Wilkins, Baltimore, Maryland. 1163 pp.

Mottet, N., Cornford, P., van den Bergh, R. C. N., De Santis, M., Fanti, S., Gillessen, S., Grummet, J., Henry, A. M., Lam, T. B., Mason, M. D., van der Kwast, T. H., van der Poel, H. G., Rouviere, O., Schoots, I. G., Tilki, D., Wiegel, T. (2020). Oncology Guidelines, Prostate Cancer. https://uroweb.org/guideline/prostate-cancer/ (accessed 10.08.2021).
Narizhneva, N. V., Tararova, N. D., Ryabokon, P., Shyshynova, I., Prokvolit, A., Komarov, P. G., Purmal, A. A., Gudkov, A. V., Gurova, K. V. (2009). Small molecule screening reveals a transcription-independent pro-survival function of androgen receptor in castration-resistant prostate cancer. Cell Cycle, 8 (24), 4155-4167.

Reedy, G. M., Cance, W. G., Kim, K., Lacasse, L., Phillips, T., Reicin, K. (2020). About Prostate Cancer. American Cancer Society.

Rosenberg, J. E. (2005). Scientists discover anti-cancer mechanism that arrests early prostate cancer. Science Daily, 4 August. https://www.sciencedaily.com/releases/2005/08/050804074959.htm (accessed 10.08.2021).

Schmelz, H. U., Sparwasser C., Weidner, W. (2006). Facharztwissen Urologie, Differenzierte Diagnostik und Therapie. Springer Medizin Verlag, Heidelberg. $736 \mathrm{~S}$.

Senapati, S., Rachagani, S., Chaudhary, K., Johansson, S. L., Singh, R. K., Batra, S. K. (2010). Overexpression of macrophage inhibitory cytokine-1 induces metastasis of human prostate cancer cells through the FAK-RhoA signaling pathway. Oncogene. 29 (9), 1293-1302.

Siegel, R. L., Miller, K. D., Jemal, A. (2019). Cancer statistics, 2019. CA Cancer J. Clin. 69, 7-34.

Soekmadji, C., Russell, P. J., Nelson, C. C. (2013). Exosomes in prostate cancer: Putting together the pieces of a puzzle. Cancers (Basel), 5 (4), $1522-1544$.

Stieve, H. (1930). Männliche Genitalorgane. In: Handbuch der mikroskopischen Anatomie des Menschen. Vol. VII Part 2. Springer, Berlin.

Strom, P., Kartasalo, K., Olsson, H., Solorzano, L., Delahunt, B., Berney, D. M., Bostwick, D. G., Evans, A. J., Grignon, D. J., Humphrey, P. A. et al. (2020). Artificial intelligence for diagnosis and grading of prostate cancer in biopsies: a population-based, diagnostic study. Lancet Oncol., 21 (2), 222-232.

Tarhan, F., Orcun, A., Kucukercan, I., Camursoy, N., Kuyumcuoglu, U. (2005). Effect of prostatic massage on serum complexed prostate-specific antigen levels. Urology, 66,1234-1238.

Thompson, I. M. (2006). PSA: A biomarker for disease. A biomarker for clinical trials. How useful is it? J. Nutr., 136, 2704 S.

van der Pol, E., Böing, A. N., Harrison, P., Sturk, A., Nieuwland, R. (2012). Classification, functions, and clinical relevance of extracellular vesicles. Pharmacol. Rev., 64 (3), 676-705.

Van Leenders, G. J. L. H., van der Kwast, T. H., Grignon, D. J., Evans, A. J., Kristiansen, G., Kweldam, C. F., Litjens, G., McKenney, J. K., Melamed, J., Mottet, N., et al. (2020). The 2019 International Society of Urological Pathology (ISUP) Consensus Conference on Grading of Prostatic Carcinoma. Amer. J. Surg. Pathol., 44 (8), e87-e99.

Watanabe, S. I., Miyata, Y., Kanda, S., Iwata, T., Hayashi, T., Kanetake, H., Sakai, H. (2009). Expression of X-linked inhibitor of apoptosis protein in human prostate cancer specimens with and without neo-adjuvant hormonal therapy. J. Cancer Res. Clin. Oncol., 136 (5), 787-793.

Yao, V., Berkman, C. E., Choi, J. K., O'Keefe, D. S., Bacich, D. J. (2010). Expression of prostate-specific membrane antigen (PSMA), increases cell folate uptake and proliferation and suggests a novel role for PSMA in the uptake of the non-polyglutamated folate, folic acid. Prostate, 70 (3), 305-316.

Zha, J., Huang, Y. F. (2009). TGF-beta/Smad in prostate cancer: An update. Zhonghua Nan Ke Xue (in Chinese), 15 (9), 840-843. 


\section{MŪSDIENU VIRZIENI PRIEKŠDZIEDZERA AUDZĒJA ETIOLOĢIJĀ, PATOĢENĒZ̄Ē UN DIAGNOSTIKĀ}

Priekšdziedzera audzējs joprojām ir otrs visbiežāk diagnosticētais ḷaundabīgais audzējs vīriešiem. 2012. gadā tas visā pasaulē tika diagnosticēts 1.1 miljoniem vīriešu, kas ir $15 \%$ no visiem diagnosticētajiem audzēju veidiem. Vēlīnās stadijās priekšdziedzera audzēja ārstēšana ir sarežğìta. Turklāt daudziem priekšdziedzera audzēja pacientiem raksturīga audzēja rezistence pret androgēnu terapiju, tāpēc tā kḷūst par metastātisku kastrācijas rezistentu slimību. Efektīvai priekšdziedzera audzēja ārstēšanai būtu nepieciešami biomarķieri, kas ḷautu izvēlēties atbilstošu ārstēšanu un prognozētu slimības gaitu. Ir izstrādātas dažādas riska klasifikācijas, kas atškir pacientus ar agrīnu priekšdziedzera audzēju atbilstoši prognozei, ieskaitot D'Amico klasifikācijas sistēmu "Cancer of the Prostate Risk Assessment Score" un "National Comprehensive Cancer Network" riska grupu klasifikāciju. Diemžēl joprojām trūkst vienotu, universālu, salīdzinoši lētu, neinvazīvu agrīnas priekšdziedzera audzēja diagnostikas metožu. Šì apskata raksta mērkis ir sniegt mūsdienīgas atziņas par priekšdziedzera audzēja riska faktoriem, patoǵenēzes mehānismiem un diagnostikas iespējām. 